\title{
Analisis Tingkat Work-Life-Balance Dan Penilaian Kinerja Terhadap Motivasi Kerja Dan Organizational Citizenship Behavior Karyawan Pt. Buma Apparel Industry Di Subang
}

\author{
Acep Durahman ${ }^{1}$, Eeng Ahman ${ }^{2}$ \\ Mahasiswa Magister Manajemen Bisnis \\ Sekolah Pasca Sarjana Universitas Pendidikan Indonesia
}

\begin{abstract}
Abstrak
Penelitian ini berjudul Analisis Tingkat Work Life Balance (WLB) dan Penilaian Kinerja Terhadap Motivasi Kerja dan Organizational Citizenship Behavior (OCB) karyawan PT. Buma Apparel Industry Subang. Berdasarkan pengamatan dilapangan, peneliti menemukan adanya data turn over karyawan yang tinggi, sehingga diduga unsur tersebut termasuk kedalam indikator variabel-variabel yang teliti. Penelitian dilakukan dengan cara menyebarkan angket kepada karyawan yang berjumlah 100 responden. Metode sampling yang digunakan yaitu simple random sampling (Becker \& Doyle, 2016). Deskripsi work life balance tertinggi pada indikator, pk merasa kurang ditilai oleh atasan pada indikator, sedangkan indikator tertinggi motivasi pada insentif, dan terendah pada persepsi gaji, sedangkan indikator OCB terendah pada indikator perilaku melebihi. Berdasarkan pengolahan data angket dengan metode analisis jalur (path analysis) dengan derajat kepercayaan $95 \%$ (alfa 0,05) dapat disimpulkan bahwa tingkat Work Life Balance karyawan PT. Buma Apparel Industry berpengaruh positif terhadap tingkat Motivasi dengan nilai koefisien beta sebesar 0,543. Sedangkan pengaruh Penilaian Kinerja terhadap motivasi tidak signifikan. Pengaruh WLB dan PK terhadap OCB tidak signifikan $(0,1)$, sedangkan tingkat motivasi terhadap OCB berpengaruh sebesar 0,2 yang temasuk kategori hubungan korelasi rendah.
\end{abstract}

Kata Kunci: Work Life Balance, Organizational Citizenship Behavior, Turn over

\section{PENDAHULUAN}

Perilaku umum karyawan di Indonesia memang tidak terlepas dari isu kenaikan upah atau gaji. Keadaan karyawan di PT. Buma Apparel Industry yang menjadi lokus penelitian tidak terjadi gejolak seperti karyawan di daerah lain seperti di wilayah Jakarta, Bogor, Tangerang. Depok dan Bekasi atau Jabodetabek (Liaw, 2015).

Target produksi di PT. Buma Apparel Industry juga tidak pernah melebihi kapasitas atau target. Karyawan dengan perilaku OCB yang tinggi akan berusaha untuk melebihi target perusahaan atau berusaha jauh lebih baik dari yang diminta. Beberapa alat dan fasilitas perusahaan juga banyak mengalami kerusakan seperti mesin jahit dan fasilitas MCK, hal ini juga menunjukkan rendahnya rasa peduli terhadap tempat kerja.

Penilaian kinerja (Performance Appraisal) adalah alat kontrol bagi organisasi untuk mengukur seberapa kuat kemampuan tim untuk mencapai tujuan. Hasil pengukuran terhadap kinerja pegawai dapat dijadikan acuan bagi manajer untuk mengevaluasi masingmasing unit kerja.

Faktor lain yang menjadi objek penelitian yaitu faktor motivasi yang melatarbelakangi keinginan untuk bekerja. Jika karyawan bekerja tanpa motivasi, tentu hasilnya tidak akan memuaskan. Kurangnya motivasi menyebabkan karyawan bermalas-malasan dan sering terjadi kemangkiran. Motivasi bisa berasal dari diri sendiri atau dari luar. Faktor dari luar diantaranya penilaian kinerja. Faktor dari dalam yaitu suasana hati yang sedang dialami karyawan tersebut sebagai respon terhadap suasana lingkungannya.

Mengelola perusahaan dengan karyawan berjumlah ribuan tentu tidak mudah, perlu teknik dan pengetahuan memadai untuk mengoperasikan dan mengendalikan kondisi karyawan. Diantara faktorfaktor yang perlu diperhatikan oleh manajer personalia 
diantaranya hal-hal yang telah dipaparkan di atas. Sebagai data pendukung penelitian, berikut rincian jumlah karyawan PT. Buma Apparel Industry, Subang.

Tabel 1.1

Data karyawan PT Buma Apparel Industry

(Berdasarkan Status Kontrak Dan Tetap)

Update : 16 November 2015
\begin{tabular}{|c|c|c|c|c|}
\hline \multirow{2}{*}{ N0 } & \multirow{2}{*}{ FACTORY } & \multicolumn{2}{|c|}{ KARYAWAN } & \multirow{2}{*}{ TOTAL } \\
\cline { 3 - 4 } & & TETAP & KONTRAK & \\
\hline \hline 1 & F1 & 1217 & 395 & 1612 \\
\hline 2 & F2 & 1169 & 333 & 1502 \\
\hline 3 & F3 & 89 & 53 & 142 \\
\hline \hline \multicolumn{2}{|c|}{ TOTAL } & $\mathbf{2 4 7 5}$ & $\mathbf{7 8 1}$ & \multirow{2}{*}{3256} \\
\hline \multicolumn{2}{|c|}{$\%$} & $\mathbf{7 6 , 0} \%$ & $\mathbf{2 4 , 0 \%}$ & \\
\hline
\end{tabular}

Info grafik dari tabel di atas dapat tergambar seperti di bawah ini :

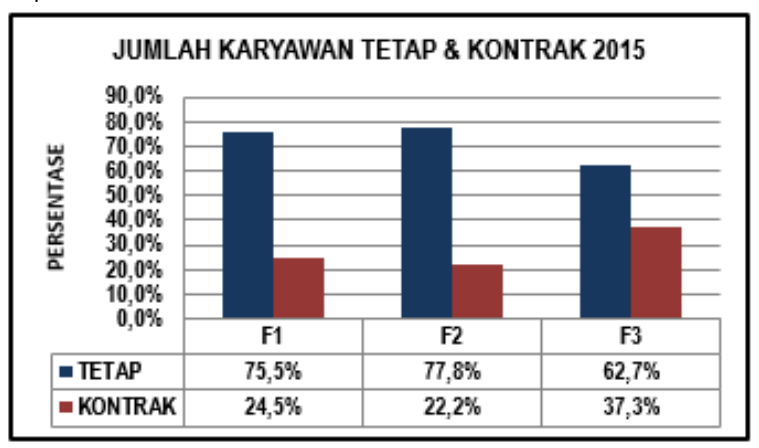

\section{Grafik 1.1}

Grafik karyawan PT BUMA APPAREL INDUSTRY

(Berdasarkan Status Kontrak Dan Tetap)

Berdasarkan grafik di atas tergambar bahwa mayoritas karyawan PT. Buma Apparel Industry adalah karyawan tetap sekitar $75 \%$ dan $25 \%$ sisanya termasuk pekerja kontrak. Status karyawan kontrak dan tetap tentu disesuaikan dengan rencana strategis perusahaan jangka pendek maupun jangka panjang sesuai fungsi pengadaan MSDM.

Proses rekrutmen tenaga kerja tetap dan kontrak diatur dalam Undang-Undang Ketenagakerjaan, oleh sebab itu, perusahaan menyediakan jalur kontrak dan tetap untuk mengakomodasi banyaknya pelamar kerja. Status karyawan kontrak dan tetap hanya berbeda pada masa kerja, karyawan dengan status kerja tetap akan lebih merasa aman dimasa depan karena ada jaminan pesangon jika diberhentikan, sedangkan tenaga kerja kontrak berhenti sesuai kontrak yang telah disepakati dengan perusahaan.

Tingkat Work Life Balance pada setiap karyawan tentu bervariasi. Penarikan kesimpulan akan bias jika peneliti tidak mendeskripsikan latar belakang sampel responden. Diantara latar belakang yang diklasifikasikan yaitu jenis kelamin karyawan, divisi kerja, usia, dan lamanya bekerja di perusahaan tersebut. Data mengenai jumlah karyawan PT. Buma Apparel Industry berdasarkan jenis kelamin diuraikan pada tabel di bawah ini :

Tabel 1.2

Data karyawan PT BUMA APPAREL INDUSTRY

(Berdasarkan Jenis Kelamin)

\begin{tabular}{|c|c|c|c|}
\hline 16-Nov-15 & LAKI - LAKI & PEREMPUAN & TOTAL \\
\hline \hline F1 & 250 & 1362 & 1612 \\
\hline F2 & 355 & 1147 & 1502 \\
\hline F3 & 90 & 52 & 142 \\
\hline TOTAL & $\mathbf{6 9 5}$ & $\mathbf{2 5 6 1}$ & $\mathbf{3 2 5 6}$ \\
\hline
\end{tabular}

Grafik tabel di atas di deskripsikan sebagai berikut

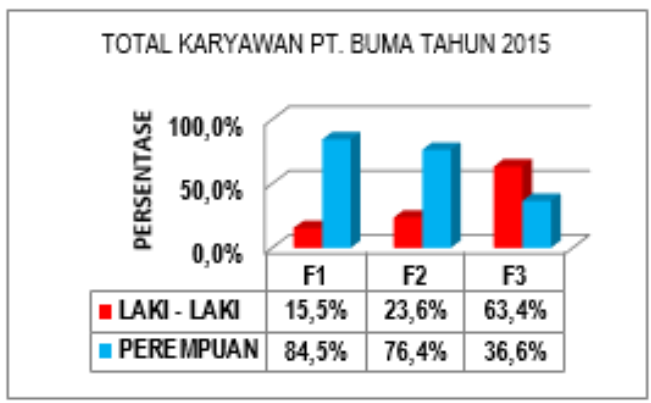

\section{Grafik 1.2}

\section{Grafik karyawan PT BUMA APPAREL INDUSTRY}

(Berdasarkan Jenis Kelamin)

Jumlah karywan PT. Buma didominasi oleh perempuan sekitar $75 \%$ dari ketiga unit produksi yang ada. Sementara jumlah karyawan laki-laki hanya sekitar $30 \%$, tetapi jumlah karyawan laki-laki sebanyak $60 \%$ pada Factory 3. Jumlah tersebut sudah disesuaikan dengan karakteristik pekerjaan dimasing-masing unit.

Salah satu indikator kurangnya motivasi kerja ialah tingginya intensitas masuk dan keluar karyawan (turn over). Berdasarkan data departemen HRD, terdapat karyawan yang berhenti dan masuk kerja pada setiap bulan. Angka turn over di PT. Buma Apparel Industry bisa diamati pada tabel dibawah ini : 
Acep Durahman ${ }^{1}$, Eeng Ahman ${ }^{2}$ - Analisis Tingkat Work-Life-Balance Dan Penilaian Kinerja Terhadap Motivasi Kerja Dan Organizational Citizenship Behavior Karyawan Pt. Buma Apparel Industry Di Subang

Tabel 1.3

Data Turn Over karyawan Oktober 2015

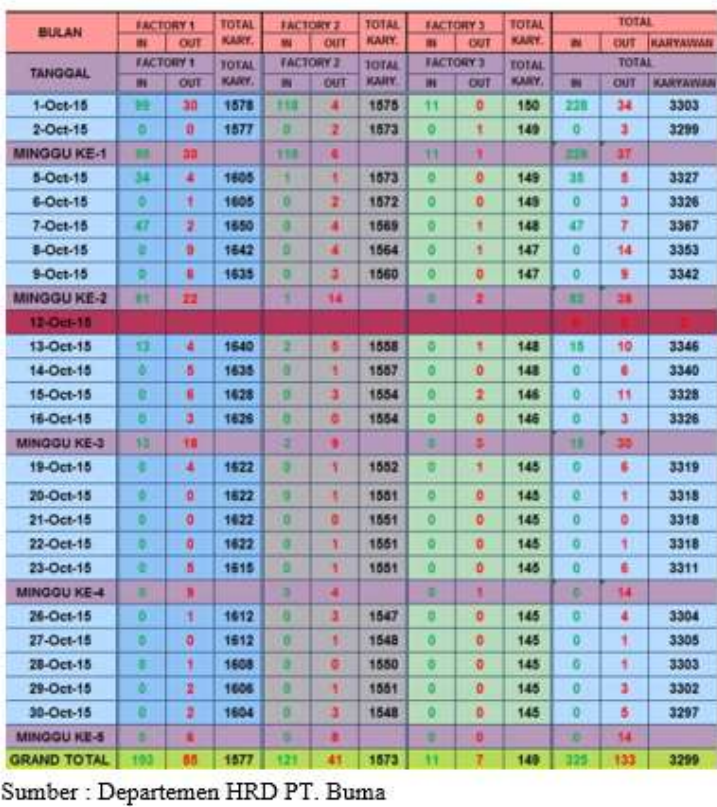

Berdasarkan tabel di atas, total jumlah karyawan yang keluar yaitu 133 orang dan yang masuk (masuk kerja) berjumlah 325 orang sampai dengan bulan Oktober 2015. Adanya angka turn over menunjukkan bahwa adanya kecenderungan karyawan untuk berhenti, meskipun sebab Pemutusan Hubungan Kerja (PHK) masih harus di teliti. Beberapa sebab PHK diantaranya, melanggar peraturan perusahaan, mengundurkan diri, habis masa kerja atau langkah perusahaan untuk efisiensi biaya pegawai (Dwiantika,2015).

Setelah melakukan pengamatan langsung dengan berkoordinasi dengan departemen HRD PT. Buma, peneliti mendapatkan data OCB karyawan pada bulan Oktober. Data tersebut pada umumnya menunjukkan OCB yang kurang memenuhi standar. Menurut pendapat manajer HRD perusahaan tersebut, OCB karyawan kurang baik dikarenakan adanya beberapa kegiatan serikat buruh yang menuntut kenaikan upah minimum, sehingga kualitas kerja karyawan terganggu. Rincian OCB bisa dideskripsikan pada tabel di bawah ini
Tabel 1.4

Data OCB Karyawan PT. Buma (Factory 1,2 dan 3) Oltober 2015

\begin{tabular}{|c|c|c|c|c|}
\hline No & Dimensi OCB & Pernyataan & $\begin{array}{l}\text { Rata-rata } \\
\text { Skor }\end{array}$ & Kriteria \\
\hline \multirow[b]{2}{*}{1} & \multirow[b]{2}{*}{ Altruism } & $\begin{array}{l}\text { Saya pemah menolong pekerjaan } \\
\text { teman dengan ikhlas }\end{array}$ & $81 \%$ & Baik \\
\hline & & $\begin{array}{l}\text { Saya siap memberi bantuan } \\
\text { kepada orang disekitar lingkungan } \\
\text { kerja saya }\end{array}$ & $72 \%$ & Kurang \\
\hline \multirow[b]{2}{*}{2} & \multirow{2}{*}{ Conscientiousness } & $\begin{array}{l}\text { Saya melakukan pekerjaan jauh } \\
\text { lebih baik dari yang diminta }\end{array}$ & $70 \%$ & sedang \\
\hline & & $\begin{array}{l}\text { Saya bekerja sesuai prosedur / } \\
\text { petunjuk }\end{array}$ & $90 \%$ & Baik \\
\hline \multirow[b]{2}{*}{3} & \multirow{2}{*}{ Courtesy } & $\begin{array}{l}\text { Saya berusaha untuk menghargai } \\
\text { orang lain }\end{array}$ & $91 \%$ & Baik \\
\hline & & $\begin{array}{l}\text { Saya berusaha untuk tidak mencar } \\
\text { masalah dengan orang lain }\end{array}$ & $70 \%$ & Kurang \\
\hline \multirow{3}{*}{4} & \multirow{3}{*}{ Sportsmanship } & $\begin{array}{l}\text { Saya bisa menyesuaikan diri } \\
\text { dengan aturan / rekan tempat saya } \\
\text { bekerja }\end{array}$ & $74 \%$ & Kurang \\
\hline & & $\begin{array}{l}\text { Saya berusaha meredam } \\
\text { permasalahan yang bukan } \\
\text { tanggungjawab saya }\end{array}$ & $88 \%$ & Baik \\
\hline & & $\begin{array}{l}\text { Saya semangat dan antusias dalam } \\
\text { bekerja }\end{array}$ & $85 \%$ & Sedang \\
\hline \multirow[b]{2}{*}{5} & \multirow{2}{*}{ Civic Virtue } & $\begin{array}{l}\text { Saya peduli terhadap tempat saya } \\
\text { bekerja }\end{array}$ & $64 \%$ & Kurang \\
\hline & & $\begin{array}{l}\text { Saya menginginkan kemajuan } \\
\text { perusahaan tempat saya bekerja }\end{array}$ & $89 \%$ & sedang \\
\hline
\end{tabular}

Tabel di atas menunjukkan data OCB karyawan PT. Buma pada bulan oktober 2015 yang mengindikasikan terdapat beberapa dimensi OCB yang dikategorikan kurang memenuhi standar. Kategori kurang terdapat pada item pernyataan memberi bantuan kepada orang lain, berusaha untuk mencari masalah dengan oraang lain, menyesuaikan diri dengan aturan, dan item kepedulian terhadap tempat kerja.

Penelitian Ruiz (2014) dan Lloyd (2015) menjadi latar belakang penelitian ini karena ada aspek yang berpengaruh positif terhadap OCB yaitu aspek perilaku etis dan aspek perhatian atasan (supervisor). Kedua aspek tersebut akan diteliti apakah ada keterkaitan dengan unsur WLB dan penilaian kinerja pada penelitian ini. Beberpa jurnal meneliti dampak OCB, seperti penelitian Yurcu et. all (2015) yang mengidentifikasi dimensi-dimensi OCB berpengaruh terhadap kesejahteraan subjektif (subjective-well being).

Pada umumnya belum banyak penelitian mengenai Work Life Balance dan menelusuri pengaruhnya terhadap motivasi dan OCB. Penelitianpenelitian terdahulu tidak menjelaskan komposisi responden menurut jenis kelamin, sedangkan pada 
penelitian ini dijelaskan bahwa mayoritas responden adalah perempuan (80\%).

\section{KERANGKA PENELITIAN \& HIPOTESIS}

Robbins dan Coulter (2012 : 358) berpendapat program bahwa work-life balance meliputi jaminan pada perawatan orang tua dan anak, perawatan, kesehatan dan kesejahteraan karyawan, dan relokasi dan lain-lain.

Kinerja itu sendiri didefinisikan sebagai hasil kerja yang dapat dicapai oleh seseorang dalam suatu perusahaan sesuai dengan wewenang dan tanggungjawab masing-masing dalam upaya pencapaian tujuan perusahaan secara legal, tidak melanggar hukum dan tidak bertentangan dengan moral atau etika (Rivai \& Ella, 2014)

Winardi (2008:6) mengemukakan bahwa motivasi adalah suatu kekuatan yang ada pada diri seseorang, yang dapat dikembangkan oleh sendirinya maupu kekuatan diluar dirinya. Motivasi pada intinya berkisar pada imbalan moneter dan nonmoneter yang dapat mempengaruhi hasil kinerjanya.

- Motivasi menjadi penting karena dengan motivasi setiap karyawan diharapkan mau bekerja keras dan antusias untuk mencapai produktivitas yang tinggi (Sunyoto,11:2012).

Menurut pendapat Aldag dan Resckhe (1997), Organizational Citizenship Behavior merupakan kontribusi individu dalam melebihi tuntutan peran di tempat kerja. OCB ini melibatkan beberapa perilaku meliputi perilaku suka menolong orang lain, menjadi volunteer untuk tugas-tugas ekstra, patuh terhadap aturan-aturan dan prosedur-prosedur di tempat kerja.

Grand Theory yang digunakan peneliti pada penelitian ini yaitu teori pertukaran sosial atau Social Exchange Theory (Emerson, 1976) dengan prinsip teori behaviorisme. Teori ini terkait dengan variabel inti dari penelitian ini yaitu OCB. Menurut Emerson, interaksi sosial yang terjadi bisa didasarkan pada keuntungan yang didapat orang dari kontribusi yang disumbangkannya.
Setelah dilakukan telaah pustaka yang mendasari perumusan masalah yang diajukan selanjutnya dibentuk sebuah kerangkan pemikiran penelitian yang akan digunakan sebagai acuan dalam pemecahan masalah. Kerangka pemikiran penelitian yang dibentuk ditampilkan pada gambar grafik di bawah ini :

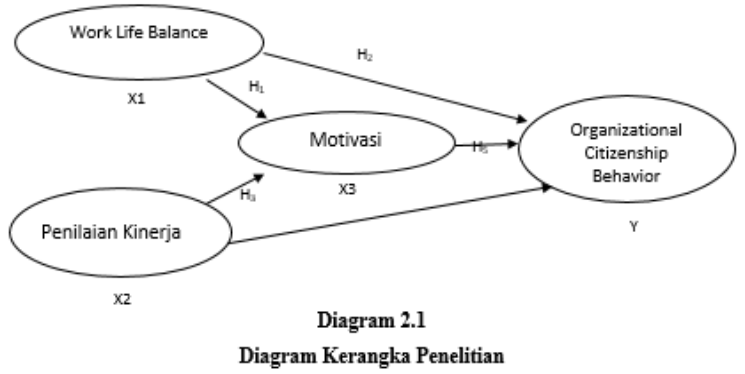

Hipotesis Penelitian

Berdasarkan uraian teoritik diagram kerangka penelitian 2.3 di atas, maka hipotesis penelitian ini dapat dirumuskan sebagai berikut :

H1 : Terdapat pengaruh yang positif Work Life Balance terhadap Motivasi kerja pada karyawan.

H2 : Terdapat pengaruh yang positif Work Life Balance terhadap Organizational Citizenship Behavior pada karyawan.

H3 : Terdapat pengaruh yang positif antara Penilaian Kinerja terhadap Motivasi Kerja pada karyawan.

H4 : Terdapat pengaruh yang positif antara Penilaian Kinerja (X2) terhadap Organizational Citizenship Behavior (Y) pada karyawan

H5 : Terdapat pengaruh yang positif antara Motivasi Kerja (X3) dengan Organizational Citizenship Behavior (Y) terhadap karyawan.

H6 : Terdapat pengaruh yang positif Work Life Balance dan Penilaian Kinerja terhadap Motivasi kerja secara simultan pada karyawan.

H7 : Terdapat pengaruh yang positif Work Life Balance, Penilaian Kinerja, dan Motivasi kerja terhadap Organizational Citizenship Behavior secara simultan pada karyawan.

\section{METODE PENELITIAN}

Objek penelitian pada tesis ini meliputi empat variabel yaitu : Tingkat Worklife Balance (X1), Penilaian 
Acep Durahman ${ }^{1}$, Eeng Ahman ${ }^{2}$ - Analisis Tingkat Work-Life-Balance Dan Penilaian Kinerja

Kinerja(X2), Motivasi Kerja (Y1) dan Organizational Citizenhip Behavior (Y2). Variabel-variabel tersebut diduga memiliki unsur keterkaitan yang akan dideskripsikan melalui metode penelitian dan pengolahan data.

Rincian unsur-unsur yang meliputi Work Life Balance diantaranya aspek mengenai keseimbangan antara kehidupan pribadi dan pekerjaan. Penilaian Kinerja melingkupi penilaian terhadap indikatorindikator kinerja, apakah dilakukan penilaian oleh perusahaan. Variabel Motivasi meliputi motivasi dari luar dan dari dalam diri karyawan, dan Variabel Organizational Citizenhip Behavior meliputi lima dimensi yaitu : (1) Alttruism, (2) Concientiousness, (3) Courtesy, (4) Sportmanship, (5) Civic Virtue.

Penelitian ini dilaksanakan di wilayah Kabupaten Subang, Kecamatan Purwadadi. Perusahaan yang dijadikan tempat penelitian yaitu PT. Buma Apparel Industry dengan produk utama perusahaan pakaian jadi.

Metode penelitian yang digunakan pada penelitian ini yaitu metode analisis jalur (path analysis).

Instrumen atau alat untuk mengukur variabelvariabel penelitian yang telah dipaparkan sebelumnya berupa angket.

Populasi dalam penelitian yaitu karyawan PT. Buma Apparel Industry yang berjumlah 3.256 orang. Untuk menentukan jumlah sampel dapat ditentukan secara purposif yaitu dengan mengadakan kesepakatan dengan manajer personalia (HRD) diperusahaan mengenai jumlah karyawan yang bisa dijadikan responden. Berdasarkan kesepakatan didapatkan jumlah responden sebanyak 100 orang.

Teknik yang digunakan untuk pengambilan sampel pada penelitian ini yaitu metode acak sederhana (Simple Random Sampling) (Becker \& Doyle, 2016).

\section{HASIL DAN PEMBAHASAN}

\section{Deskripsi Work Life Balance}

Berdasarkan pengolahan data dan uji statistik, dapat diketahui bahwa tingkat Work Life Balance karyawan PT. Buma Apparel Industry lebih dominan pada indikator pemilihan jam kerja yang fleksibel, dan ditentukan oleh ketepatan masuk dan keluar jam kerja, dan ditunjukan juga dengan kecenderungan karyawan untuk bergabung dengan serikat buruh.

Indikator pemeilihan jam kerja yang fleksibel dikategroikan baik dikarenakan perusahaan memberikan kesempatan kepada karyawan apakah mau memilih jam kerja lebih atau tidak dalam seminggu. Indikator ketepatan waktu masuk kerja dan berserikat berkaitan dengan psikologi karyawan yang mayoritas permepuan sehingga lebih mudah mengikuti aturan-aturan perusahaan.

Dengan demikian perusahaan sudah mampu mengelola pemilihan jam kerja, ketepatan waktu kerja, dan kebebasan karyawan untuk berserikat. Sedangkan tingkat Work Life Balance yang ada pada kategori kriteria sedang yaitu indikator keseimbangan membagi waktu kerja dengan keluarga, dan menjadi anggota komunitas. Kedua indikator tersebut dikategorikan sedang karena mayoritas karyawan adalah perempuan. Sebagaimana diketahui secara tugas dan kewajiban perempuan memang lebih banyak untuk mengurus keluarga, jadi berdasarkan hasil angket, karyawan PT. Buma Apparel Industry kurang bisa membagi waktu antara pekerjaan dengan keluarga. Sedangkan menjadi anggota komunitas misalnya klub olahraga (sepakbola, badminton dll), klub otomotif (motor, mobil) juga dikatgorikan kurang. Menyukai dan menjadi anggota komunitas hobi merupakan aktivitas yang banyak diikuti oleh karyawan pria.

Mencermati paparan di atas maka tingkat Work Life Balance dapat dikategorikan baik dengan catatan bahwa mayoritas responden karyawan adalah permpuan, karena keseluruhan populasi karyawan didominasi oleh perempuan.

\section{Deskripsi Penilaian Kinerja}

Berdasarkan pengolahan data dan uji statisktik, dapat diketahui bahwa tingkat Penilaian Kerja 
karyawan PT. Buma Apparel Industry mayoritas indikator yang diobservasi berada pada level baik, hanya tiga indikator yang termasuk kategori sedang yaitu indikator penilaian terhadap prakarsa, indikator penilaian terhadap kesetiaan, dan penilain terhadap tanggungjawab.

Penilaian kinerja ditinjau dari indikator penilaian terhadap kualitas dan kuantitas kerja dikategorikan baik. Hal ini bisa terjadi karena ketatnya pengawasan yang dilakukan manajer. Terutama manajer produksi. Disetiap factory (unit pabrik) terdapat beberapa supervisor yang mengawasi kinerja karyawan dengan mengecek hasil pekerjaan dan jumlah produksi yang bisa dihasilkan setiap hari.

Indkator lain yang dikategorikan baik yaitu indkator penilaian terhadap kedisiplinan. Di PT. Buma telah disediakan beberapa Standard Operation Procedure (SOP) untuk masing-masing unit kerja, sehingga aspek kedisiplinan lebih mudah dikontrol oleh atasan, misalnya pada aspek kedisiplinan masuk kerja, karyawan dengan ketidak hadiran melebihi tiga hari akan diberikan Surat Peringatan 1, kemudian 2 dan pemberhentian.

Selain itu, indikator penilaian terhadap kerja sama, indkator terhadap kepribadian, dan indikator penilaian kecakapan termasuk kedalam kategori baik. Hal ini menjelaskan bahwa karyawan merasa perushaan menilai mereka dari aspek kepribadian dan kecakapan cukup intens. Tugas penialaian tersebut dilakukan oleh kepala produksi untuk kemudian dilaporkan kepada manajer HRD.

Penilaian kinerja yang dilakukan oleh PT. Buma Apparel Industry dilakukan secara periodik, ada yang bulanan dan tahunan. Secara bulanan yaitu menyangkut persentase kehadiran karyawan, rata-rata produksi pakaian jadi yang dihasilkan dari ketiga factory yang dimiliki dan pengukuran lainnya. Hasilnya indkator penilaian kesetian untuk tetap didalam organisasi (perusahaan) kurang begitu diperhatikan perusahaan. Hal ini kemungkinan disebabkan ada beberapa responden yang berstatus karyawan kontrak.

\section{Deskripsi Motivasi Kerja}

Berdasarkan pengolahan data dan uji statistik yang telah dipaparkan sebelumnya dapat diketahui bahwa tingkat motivasi kerja karyawan PT. Buma Apparel Industry ditinjau dari indikator penempatan pegawai dan pemberian insentif termasuk kategori baik. Sedangkan indikator berada pada level sedang yaitu indikator upah yang layak, indikator mempertahankan harga diri, indikator memenuhi kebutuhan rohani, dan indikator rasa aman dimasa depan.

Motivasi kerja merupakan penggerak, dorongan dan alasan seseorang bekerja. Tidak bisa diingkari bawhwa motivasi utama dalam bekerja ialah gaji yang layak. Berkaitan dengan hal ini, persepsi karyawan PT. Buma yang mengaggap upah belum layak bisa disebabkan UMR (Upah Minimum Regional) yang ditetapkan pemerintah setempat (Subang) masih dibawah UMR di daerah lain. Begitu juga dengan indikator menimbulkan rasa aman di dimasa depan, hal ini disebabkan belum adanya jaminan pesangon yang layak dari perusahaan ketika masa kerja sudah habis dan harus berhenti (pensiun). Pekerja kontrak juga akan berpresepsi yang sama tentang jaminan apakah ia akan diangkat menjadi karyawan tetap atau tidak.

Indikator penempatan yang sesuai berkategori baik karena manajemen perusahaan telah melakukan perekrutan dengan baik. Beban pekerjaan disesuaikan dengan latar belakang keahlian dan pendidikan karyawan untuk masing-masing unit produksi dari bagian sewing sampai mekanik.

Sedangkan pemberian insentif berupa bonus atau Tunjangan Hari Raya selalu diberikan oleh perusahaan, sehingga persepsi karywan terhadap insentif cukup baik. Bonus juga diberikan jika lini produksi berhasil mencapai target sesuai jadwal yang telah ditetapkan, karena perusahaan selalu menjaga kepercayaan klien dengan memenuhi pesanan sesuai yang diharapakan.

Indikator mempertahankan harga diri dipersepsikan sedang karena pada umumnya, status karyawan kurang diminati dibandingkan dengan bekerja sebagai pegawai negeri sipil yang memiliki jaminan pensiun.

4. Desrkripsi Organizational Citizenship Behavior (OCB) 
Berdasarkan pengolahan data dan uji statistik juga dapat diketahui bahwa tingkat Organizational Citizenship Behavior karyawan PT. Buma Apparel Industry berada pada level sedang. Berdasarkan pengamatan lima dimensi OCB maka dimensi Conscientiousness dikategorikan baik. Sedangkan empat dimensi lainnya berkategori sedang yaitu pada dimensi Altruism, dimensi Courtesy, dimensi Sportmanship, dan dimensi Civic Virtue.

Dimensi Altruism berkategori baik pada indikator ketulusan menolong dan indikator memberi bantuan kepada rekan yang membutuhkan. Hal ini bisa terjadi karena berhubungan dengan psikologi perempuan yang lebih mengandalkan perasaan.

Sedangkan pada dimensi Conscientiousness, kedua indikator yaitu indikator perlaku yang melebihi prasyarat minimum dan indikator bekerja sesuai prosedur berada pada level sedang. Perilaku ini bisa terjadi dikarenakan kurangnya penghargaan terhadap perilaku karyawan yang bekerja lebih giat, dan kurangnya pengawasan supervisor terhadap ketepatan prosedur bekerja para karyawan.

Indikator lain yang berkategori sedang yaitu indikator rasa memiliki terhadap perusahaan dan indikator memajukan perusahaan. Rasa memiliki (sense of belonging) bisa tumbuh jika karyawan merasakan manfaat yang lebih di tempat pekerjaanya. Sedangkan keinginan memajukan perushaan lebih kepada level manajer tingkat menengah dan atas, sehingga karyawan kurang begitu peduli, dan hanya memprioritaskan mendapatkan penghasilan.

Pada dimensi Courtesy indikator menghargai orang lain berkategori baik sedangkan indikator tidak membuat masalah dengan orang lain berkategori sedang. Keadaan ini menunjukkan adanya beberapa peristiwa yang mengundang percekcokan diatara karyawan ketika bekerja.

Indikator beradaptasi dengan lingkungan kerja berada pada kategori baik, indikator tidak mudah mengeluh juga berada pada level baik, sedangkan indikator semangat kerja berada pada level sedang.

\section{Pengaruh Work Life Balance terhadap Motivasi Kerja}

Berdasarkan hasil pengolahan data dan uji statistik dapat diketahui bahwa Work Life Balance berpengaruh terhadap motivasi kerja. Tingkat Work Life Balance karyawan di PT. Buma Apparel Industry umumnya berada pada kondisi baik. Hal tersebut dapat mempengaruhi tingkat motivasi kerja karena secara langsung atau tidak, psikologi karyawan dipengaruhi oleh kehidupannya diluar pekerjaan.

Kehidupan karyawan yang seimbang menyebabkan tingginya motivasi kerja. Keadaan tersebut bisa tercipta karena perusahaan memberikan kebebasan memilih jam kerja yang sesuai dengan pembagian waktu bekerja dan waktu keluarga bagi seitap karyawan. Perusahaan juga memberikan kesempatan kepada karyawan untuk berserikat dan mengikuti hobi, bahkan dilingkungan pabrik disediakan beberapa fasilitas olah raga seperti lapangan sepak bola, baset, studio radio, dan fasilitas lain untuk menyalurkan hobi karyawan.

\section{Pengaruh Penilain Kinerja terhadap Motivasi}

Berdasarkan hasil pengolahan data dan uji statistik dapat diketahui bahwa tidak terdapat pengaruh antara Penilaian Kinerja dengan motivasi. Tingkat penilaian kinerja karyawan pada umumnya berkategori baik. Karyawan merasa semua pekerjaan dan hasil kerjanya ditilai oleh atasan. Akan tetapi, penilaian kinerja yang baik ternyata tidak berpengaruh terhadap motivasi. Hal ini dimungkinkan motivasi kerja karyawan PT. Buma Apparel Industry lebih cenderung kepada penghasilan (gaji) daripada Penialian Kinerja. Baiknya penialian terhadap kreativitas, kerja sama dan prakarsa tidak menimbulkan motivasi yang signifikan pada karyawan. Kemungkinan ada penyebab lain yang membuat karyawan termotivasi., misalnya pengaruh kompensasi, gaya kepemimpinan ataupun jenjang karir.

\section{Pengaruh Work Life Balance dan Penilain Kinerja terhadap Motivasi secara simultan}


Berdasarkan hasil pengolahan data dan uji statistik dapat diketahui bahwa tingkat Work Life Balance dan tingkat Penilaian Kinerja berpengaruh secara positif terhadap Motivasi Kerja. Hal ini terjadi karena keadaan kehidupan pribadi karyawan yaitu keluarga, teman berada dalam keadaan seimbang (balance) ditambah dengan penilaian kinerja dari perushaan, sehingga karyawan lebih termotivasi dalam bekerja.

\section{Pengaruh Work Life Balance terhadap Organizational Citizenship Behavior \\ Berdasarkan hasil pengolahan data dan uji} statistik dapat diketahui bahwa tingkat Work Life Balance tidak berpengaruh terhadap tingkat Organizational Citizenship Behavior karyawan PT. Buma Apparel Industry Subang. Tingkat kehidupan yang seimbang antara bekerja dan berkeluarga ternyata tidak mempengaruhi perilaku karyawan sebagai warga dari perusahaan. Kondisi tersebut terjadi karena adanya perbedaan lingkungan keluarga dengan lingkunga kerja. Penelitian serupa juga mendapatkan hasil yang sama, bahwa konflik keluarga dan pekerjaan tidak berpengaruh terhadap tingkat OCB (Tziner \& Sharoni,2014)

Keadaan kehidupan keluarga lebih longgar terhadap disiplin dibandingkan dengan di pabrik yang penuh dengan peraturan. Adanya beberapa responden yang berstatus cerai juga menyebabkan tidak adanya pengaruh yang signifikan terhadap OCB. Latar belakang pendidikan yang masih mengakomodasi lulusan SD dan SMP juga menjadi penyebab tidak adanya pengaruh WLB terahdap OCB. Mislanya pada indikator menginginkan kemajuan perusahaan yang memerlukan tingkat penalaran yang lebih tinggi daripada hanya bekerja secara fisik.

\section{Pengaruh Penilaian Kinerja terhadap Organizational Citizenship Behavior}

Berdasarkan hasil pengolahan data dan uji statistik dapat diketahui bahwa tingkat Penilaian Kinerja berpengaruh positif terhadap OCB karyawan. Berbeda dengan WLB yang tidak berpengaruh, Penialian Kinerja karyawan mempunyai dampak terhadap perilaku kewargaan (OCB). Dikarenakan manajemen perusahaan mengawasi kinerja dan menuliskannya dalam laporan hasil kinerja maka bisa mendorong karyawan melakukan hal-hal yang ada pada indikator OCB. Mislanya menunjukkan semangat kerja dan memelihara barang-barang perusahaan seperti mesin jahit, alat setrika dan lainnya.

Pengaruh positif kinerja terhadap OCB sejalan dengan penelitian Purwaningrum (2014) yang menyatakan bahwa penilaian kinerja berpengaruh terhadap semangat kerja yang merupakan bagian dari OCB pada dimensi Sportmanship. Lebih diperinci oleh Zheng et all (2011) yang menekankan OCB dipengaruhi oleh Proses penilaian kinerja melalui komitmen afektif.

\section{Pengaruh Motivasi Kerja terhadap Organizational Citizenship Behavior}

Berdasarkan hasil pengolahan data dan uji statistik dapat diketahui bahwa Tingkat Motivasi Kerja berpenaruh positif terhadap OCB. Kondisi motivasi karyawan yang berada pada kondisi baik akan mempengaruhi keadaan OCB. Hal ini sejalan dengan yang dikemukanan Antonio dan Eddy (2014) bahwa motivasi dan kepuasan kerja berpengaruh positif terhadap OCB. Ibrahim dan Aslinda (2014) mendetailkan motivasi intrinsik lebih berpengaruh terhadap OCB dibandingkan dengan motivasi ekstrinsik.

Perilaku karyawan yang ada pada kelima dimensi OCB bisa muncul dikarenakan adanya motivasi dalam diri karyawan, baik motivasi internal maupun motivasi eksternal. Dengan demikian jika motivasi karyawan rendah maka diasumskan OCB nya pun akan rendah.

\section{Pengaruh Work Life Balance, Penilaian Kinjera dan Motivasi terhadap Organizational Citizenship Behavior secara simulatan}

Berdasarkan hasil pengolahan data, uji statistik dan uraian sebelumnya dapat diketahui bahwa Tingkat Work Life Balance, Tingkat Penilaian Kinerja dan Motivasi Kerja berpengaruh positif terhadap OCB. Ketiga variabel bebas yang dalam keadaan kondisi baik bisa mempengaruhi perilaku OCB karyawan.

Perilaku OCB yang terdiri dari lima dimensi yaitu Dimensi Altruism, Dimensi Consciousness, dimensi 
Acep Durahman ${ }^{1}$, Eeng Ahman ${ }^{2}$ - Analisis Tingkat Work-Life-Balance Dan Penilaian Kinerja Terhadap Motivasi Kerja Dan Organizational Citizenship Behavior Karyawan Pt. Buma Apparel Industry Di Subang

Courtesy, dimensi Sportmanship, dan dimensi Civic Virtue akan muncul pada diri karyawan jika dipengaruhi oleh tingkat kehidupan karyawan yang seimbang (WLB), dipengaruhi juga oleh tingkat Penilaian Kinerja yang baik, dan Motivasi yang tinggi. Misalnya mengenai aspek menginginkan kemajuan perusahaan bisa ada jika motivasi berupa gaji, insentif atau jaminan hari tua sudah dinyatakan terjamin.

\section{KESIMPULAN}

Berdasarkan hasil pengolahan data dan pembahasan yang dikemukakan pada bab sebelumnya, selanjutnya dapat disusun beberapa kesimpulan mengenai penelitian sebagai berikut :

1. Tingkat Work Life Balance karyawan PT. Buma Apparel Industri Subang tertinggi pada indikator pemilihan jam kerja yang fleksibel, persepsi terendah mengenai Work Life Balance terdapat pada indikator bisa membagi waktu kerja dan keluarga. Tingkat Penilaian Kinerja di PT. Buma Apparel Industry berada pada lebel baik. Persepsi Penilain Kinerja tertinggi pada indikator penilaian terhadap kedisiplinan. Sedangkan persepsi terendah terdapat pada indikator penilaian terhadap prakarsa. Tingkat motivasi karyawan PT. Buma Apparel Industry Subang termasuk tinggi. Tingkat motivasi karyawan memiliki persepsi tertinggi pada indkator penempatan pegawai yang sesuai, sedangkan persepsi terendah pada indikator upah atau gaji yang layak. Tingkat Organizational Citizenship Behavior karyawan memiliki persepsi tertinggi pada indikator mudah beradaptasi dengan lingkunga kerja (Dimensi Sportmanship), sedangkan persepsi terendah yaitu pada indikator perilaku yang melebihi prasyarat minimum pada dimensi Conscientiousness.

2. Work Life Balance dan Penilaian Kinerja secara simultan memiliki pengaruh terhadap tingkat motivasi kerja karyawan di PT. Buma Apparel Industri Subang pada kategori sedang. Dukungan keseimbangan kehidupan kerja dan Penilaian Kinerja dapat mempengaruhi tingkat motivasi karyawan.
3. Tingkat Work Life Balance berpengaruh secara langsung terhadap tingkat motivasi kerja karyawan di PT. Buma Apparel Industry Subang. Tingkar penaruh berada pada level cukup kuat. Semakin tinggi tingkat Work Life Balance maka tingkat motivasi karyawan akan semakin tinggi.

4. Tingkat Penilaian Kinerja tidak berpengaruh secara sifnifikan terhadap tingkat Motivasi karyawan PT. Buma Apparel Industry Subang. Kondisi Penilaian kinerja yang berada pada kondisi baik ataupun sedang tidak akan berpengaruh terhadap tingkat motivasi kerja karyawan.

5. Tingkat Work Life Balance, Tingkat Penilaian Kinerja dan Tingkat Motivasi secara simultan berpengaruh positif terhadap tingkat Organizational Citizenship Behavior karyawan PT. Buma Apparrel Industry Subang. Tingkat pengaruh berada pada level sangat rendah.

6. Tingkat Work Life Balance tidak berpengaruh secara langsung terhadap tingkat Organizational Citizenship Behavior karyawan PT. Buma Apparrel Industry Subang.

7. Tingkat Penilaian Kinerja berpengaruh langsung terhadap tingkat Organizational Citizenship Behavior karyawan PT. Buma Apparrel Industry Subang. Tingkat pengaruh berada pada level sangat rendah.

8. Tingkat Motivasi berpengaruh langsung terhadap tingkat Organizational Citizenship Behavior karyawan PT. Buma Apparrel Industry Subang. Tingkat pengaruh berada pada level rendah.

\section{REKOMENDASI}

Bagi penelitian selanjutnya, akan lebih menarik jika mengkaji tingkat Organizational Citizenship Behavior lebih dari satu perusahaan, analisis bisa berupa perbandingan karyawan swasta dan negeri.

Jumlah responden penelitian sebaiknya diperbanyak, sesuai dengan proporsi jumlah populasi secara keseluruhan. Jika sampel semakin mendekati 
populasi maka hasilnya akan lebih akurat sesuai dengan komposisi karakteristiknya.

Penelitian mengenai Organizational Citizenship Behavior bisa mendeskripsikan responden menjadi lebih detail seperti dikelompokan berdasarkan status menikah, menikah belum punya anak, dan belum menikah

\section{DAFTAR PUSTAKA}

Aldag, R., and Resckhe, W (1997) Employee Value Added: Measuring Discretionary Effort and Its Value To The Organizanization . New York. Center for Organizational Effectiveness Inc.

Antonio, Nio Erick \& Eddy (2014). Pengaruh motivasi dan kepuasan kerja karyawan terhadap OCB di CV Supratex. Online tersedia di : [http://studentjournal.petra.ac.id/index.php/ma najemen-bisnis/article/viewFile/1545/1396]

Becker, Rachel \& Drew Doyle. (2016). Sampling in SAS

${ }^{\circledR}$ using Proc Survey Select.

Dwiantika, Nina (2015). Ada Potensi PHK 100.000 Tenaga Kerja. Online tersedia di : [http://bisniskeuangan.kompas.com/read/2015/ 09/02/070712926/.Ada.Potensi.PHK.100.000.Ten aga.Kerja.]

Emerson, Richard M. (1976). Social Exchange Theory. Annual Review of Sociology, Vol 2 Page 335-362.

Ibrahim, M. Akmal \& Aslinda (2014). The Effect of Motivation on Organizational Citizenship Behavior (OCB) at Telkom Indonesia in Makassar. Journal of Administrative Science on Organization Vol. 21. Page 114-121

J. Lloyd, et all, (2015). Is My Boss Really Listening to Me? The Impact of Perceived Supervisor Listening on Emotional Exhaustion, Turnover Intention, and Organizational Citizenship Behavior. Journal of Bussines Ethic. 130:509-524.

Liaw, Hindra (2015). 5 Hal tentang Demo Buruh 1 September. Online tersedia di : [http://megapolitan.kompas.com/read/2015/09/ 01/07030071/5.Hal.tentang.Demo.Buruh.1.Septe mber]

Purwaningrum, Listianty (2014). Pengaruh penilaian kinerja terhadap semangat kerja (studi pada
Karyawan Agiomultimex). Online tersedia di : [http://administrasibisnis.studentjournal.ub.ac.id /index.php/jab/article/view/360/555]

Rivai, Veithzal \& Ella Jauvani Sagala (2014). Manajemen Sumber Daya Manusia untuk Perusahaan : Dari Teori ke Praktik (Edisi 3). Rajawali Pers. Jakarta

Ruiz-Palomino, Pablo \& Ricardo (2014). Ethical Culture, Ethical Intent, and Organizational Citizenship Behavior: The Moderating and Mediating Role of Person-Organization Fit. Journal of Bussines Ethic 120:95-108.

Sunyoto, Danang MM. (2012). Teori, Kuesioner, dan Analisis Data Sumber Daya Manusia (Praktik Penelitian). Penerbit CAPS. Yogyakarta.

Tziner, Aharon \& Gil Sharoni (2014).Organizational citizenship behavior, organizational justice, job stress, and work-family conflict: Examination of their interrelationships with respondents from a non-Western culture. Journal of Work and Organizational Psychology 30 Page 35-42.

Winardi, J. (2008). Motivasi dan Pemotivasian dalam manajemen. Raja Grafindo Persada. Jakarta

Yurcu, Gulseren et. All (2015). The Effect of Organizational Citizenship Behavior on Subjective Well-Being. International Journal of Business and Social Science. Vol. 6 No 8. Page 120-130

Zheng,Wei \& Mian Zhang \& Ha Li (2011). Performance Appraisal Proses and Organizational Citizenship Behavior. Journal of Managerial Psychology Vol 27. Page $732-752$ 